\title{
Reflections on Reflectivity: Comments on Evan Thompson's Waking, Dreaming, Being
}

Jay L. Garfield

Smith College, jgarfield@smith.edu

Follow this and additional works at: https://scholarworks.smith.edu/phi_facpubs

Part of the Philosophy Commons

\section{Recommended Citation}

Garfield, Jay L., "Reflections on Reflectivity: Comments on Evan Thompson's Waking, Dreaming, Being" (2016). Philosophy: Faculty Publications, Smith College, Northampton, MA.

https://scholarworks.smith.edu/phi_facpubs/3 


\section{PROJECT MUSE}

Reflections on Reflectivity: Comments on Evan Thompson's

Waking, Dreaming, Being

Jay L. Garfield

Philosophy East and West, Volume 66, Number 3, July 2016, pp. 943-951 (Article)

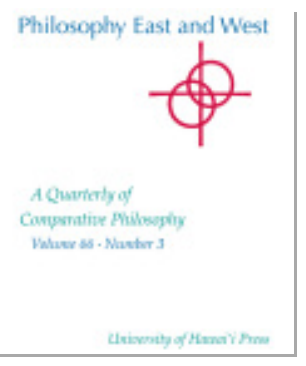

Published by University of Hawai'i Press

DOI: https://doi.org/10.1353/pew.2016.0069

$\Rightarrow$ For additional information about this article https://muse.jhu.edu/article/626969 
Reflections on Reflectivity: Comments on Evan Thompson's Waking, Dreaming, Being

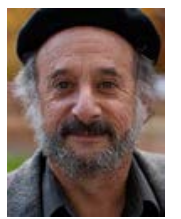

\section{Jay L. Garfield}

Smith and Harvard Divinity School

University of Melbourne; Central University of Tibetan Studies

Evan Thompson has written a marvelous book. Waking, Dreaming, Being blends intellectual autobiography, phenomenology, cognitive science, studies in Buddhist and Vedānta philosophy, and creative metaphilosophy in an exploration of what it is to be a person, of the nature of consciousness, and of the relation of contemplative to scientific method in the understanding of human life. I have learned a great deal from it, and the community of philosophers and cognitive scientists will be reading and discussing it for some time. But I have come to criticize Thompson, not to praise him. Here I raise a few issues regarding Thompson's treatment of the self and the connections between his own account and the Madhyamaka and Yogācāra accounts with which he juxtaposes it, and then turn to his treatment of consciousness and end up with some questions about his commitment to the reflexivity of awareness. But I emphasize that these sets of worries are specific and local, and should be seen in the context of genuine admiration for this fine volume and for its author.

\section{The Self}

I would like to begin by focusing on Thompson's appeal to Candrakīrti in his defense of a view that there is in fact a self. Now, I have appealed to Candrakīrti's arguments in favor of the view that there is no self (Garfield 2015, pp. 111-115). There are two questions here. First, what does Candrakīrti say? Second, is Candrakīrti right? These will help us answer another question: Is Thompson right? Thompson says:

But here's the crucial point-Candrakīrti doesn't conclude that there is no self. That would be to succumb to the nihilistic extreme, which says that since the self has no independent existence, it has no existence at all. Instead, Candrakīrti concludes that the self is dependently arisen. In other words, the self exists dependent on causes and conditions, including especially how we mentally construct it and name it in language.

Recall that in Prāsanigika Madhyamaka the idea that whatever is dependently arisen depends for its existence on a basis of designation, a designating cognition and a term used to designate it. In the case of the self, the five aggregates are the basis of designation, the thought that projects "self" onto the aggregates is the designating cognition, and the pronoun " $\mathrm{I}$ " is the term used to designate it. (2015, p. 364)

He concludes this discussion by saying: 
Candrakirti . . . says that the fundamental illusion is that we take the self to exist by virtue of its own being, when in reality its existence is dependent. The illusion is cognitive and existential. (p. 365)

So, let us be clear about what Thompson is saying. He argues that Candrakīrti correctly says that while there is no independent self, there is a real, dependent self, and that the middle path that Candrakirti seeks is a midpoint between reifying the self as an independent, substantial existent and a nihilistic position according to which there is no self at all. It is important first of all to get the philology right. So let us look at the locus classicus for Candrakīrti's view, a passage late in chapter 6 of the Madhyamakāvatāra-bhāṣya. Here is what Candrakīrti says in my translation of the Tibetan edition:

158 Although, neither from the standpoint of reality, nor conventionally

Is it demonstrated to exist in any of the seven possible ways,

Conventionally, and without analysis,

It is designated in dependence upon its parts.

... In this way, without any analysis, on the basis of such things as blueness, sensation, [and] the other aggregates are things designated. Therefore, they are only maintained to have arisen on the basis of conditions in accord with dependent origination and so are mere dependent designations. Our position does not contradict ordinary experience. . . . (1992, pp. 258-259)

162 Thus, on the basis of mundane conventions, It is even said that the self is the appropriator of The aggregates, their domains, and the sense faculties And as the appropriator is an agent. (pp. 262-263)

Up to this point, Thompson is smiling. While things might be a bit ambiguous, it certainly looks like things could go his way. After all, Candrakīrti does say that "it is said that the self is the appropriator ... and . . . is the agent," and that sounds like an affirmation of a self. But look at the next verse:

163 But since there is no such entity, it is not permanent.

Nor is it impermanent, arisen, or destroyed.

It has no characteristic such as identity.

Nor is it different from anything. (p. 263)

This self that is designated on the basis of the aggregates-although it is dependent in this way-since it does not exist is not really dependent, and does not exist at all. . . .

165 Since without an agent there is no action

Without a self, there is no "mine."

So, by seeing that both I and mine are empty,

Practitioners become completely liberated. (p. 264)

Candrakirti does not argue that this self that is "said to be the appropriator and the agent" is real at all. He argues instead that it is completely non-existent. By Thomp- 
son's lights, then, even the glorious Candrakīrti has fallen into the abyss of nihilism. Of course this doesn't settle much of importance. Thompson might be wrong about Candrakīti, but right about the self. And Candrakìrti might not be right about things. He might be a nihilistic fool. Or, we might be enmeshed in a verbal quibble about the English word self, the Sanskrit word ātman, and the Tibetan word bdag. Let's come back to these questions by taking a detour through some other remarks on the subject of the self.

In the first sentence of the introduction to his book, Thompson says:

The central idea of this book is that the self is a process, not a thing or an entity. The self isn't something outside experience, hidden either in the brain or in some immaterial realm. It is an experiential process that is subject to constant change. We enact a self in the process of awareness, and this self comes and goes depending on how we are aware. (p. xxxi)

And indeed this is the view of the self for which Thompson argues throughout the text. And indeed this is a middle path of sorts between a particular pair of two extremes. The self is not a thing: that would be the extreme of reification. But neither is it nothing: that would be the extreme of nihilism (to which we have seen, by Thompson's lights, Candrakīrti himself might be committed). Instead it is a real process, a process that is both enacted and experienced. And of course, processes are one kind of real thing. Thompson tells us more about the nature of the enaction that creates the self:

\section{4}

... [T] he crucial ingredient that takes us from a self-specifying system to a full-fledged I-making system is that of being a "self-designating" system. A self-designating system is one that can designate itself as a self. This means that it can attend to its changing experiential states and conceive of itself as the subject of those states. (p. 344)

Memory and prospection are the crucial mental capacities enabling you to think of yourself as an " $\mathrm{I}$ " who endures through time as a thinker of thoughts and a doer of deeds. Memory and prospection create a personal and historical sense of self because they enable you to think of yourself as having a unique story line through time. In this kind of self-projection-also known as mental time travel-every memory of expectation you encounter normally presents itself as yours, as belonging to you, where you feel as if you're one and same self who endures through time as the subject of those experiences. (p. 348)

I want to put this back in the terms of Buddhist philosophy, to facilitate seeing just what its relation is to the position of Candrakīrti, and just why I am so suspicious of it. The model of self-creation here is entirely first-person, a psychological account of what we call in Sanskrit āhamkāra, or self-construction. The self-designating system, in this view, is already a self, in the sense that it creates its sense of itself by itself. It creates the sense that it is an appropriator, even as it appropriates its history, future, experiences, and body. It is an autobiographical self, and it supervenes on the history of a single organism. That is the self as Candrakirti claims that it is understood by 
ordinary folk in verse 162. In Buddhist doxography, that is the self of the school called the Pudgālavādins, or proponents of a real person, who argued that the self is a real thing neither identical to nor different from the aggregates, but supervenient upon them. This is a self that, like Thompson's processes, is not independent, but is a real thing, not identical with the aggregates, but existent in dependence on them, narrowly supervenient upon them (Garfield 2015, pp. 109-111).

In verses 163 and 165 and the commentary on them Candrakīrti explicitly rejects this position. He argues that there is no such thing at all, not that it is a real process. The illusion to which Candrakirti alludes is the illusion to which Thompson, I fear, succumbs, his allusion to Candrakirti notwithstanding. And that is the illusion that when we seek the self with which we identify, the referent of "I," we find something. That is a more profound critique of the self than one according to which we find the wrong thing. Now to be sure, Thompson agrees with everyone in the Buddhist tradition that we don't find a substantial entity, a soul, or an ātman, that persists unchanging through our life or lives, and whose nature is independent of our actions, thoughts, and imputations. But he does agree with the Pudgālavādins that we find something, namely a constructed process. Here is what he says about this:

\begin{abstract}
Although the enactive account of the self that I'm proposing is close in one way to the Yogācāra account, it also differs from it in another important way. Although I agree with Yogācara that our sense of self or "I-Me-Mine" is mentally constructed, I don't think it follows that there is no self, or that the appearance of the self is nothing but an illusion. Although some illusions are constructions, not all constructions are illusions. The self is a case in point. To say that the sense of self is a mental construction-or rather that it's a process under constant mental and bodily construction-doesn't logically imply that there is no self or that the sense of self presents an illusion. (p. 359)
\end{abstract}

\title{
361
}

[T] he minimal notion of self that's crucial for "I-Me-Mine" thinking is that of a subject of experience and an agent of action, not that of a substantially existent ego. Thinking of myself in this way-as a subject and agent-enables me to think of some experiences and actions as mine and not yours, and of some experiences and actions as yours and not mine. This provides a perfectly legitimate and valuable notion of self and doesn't require thinking of you or me as substantially existent entities. (p. 361)

So, Thompson and Candrakīrti do disagree, and the disagreement is not merely verbal. But who is right? I fear that Candrakīrti is. There is an illusion pervasive in human self-conception; Thompson, his Pudgālavādin forebears, and Candrakīrti are all right to focus on that problem. But Candrakīrti sees more deeply into the matter. The illusion is that this construction is an individual matter, that we can isolate the referent of " $\mathrm{I}$ " at all, and that there is a unified subject of experience and agent of action.

Candrakīti grants with Thompson that our sense of self is constructed, but he, with the Yogācārins he criticizes so trenchantly on other matters, believes that what is constructed itself is an illusion, in that it presents us to ourselves in a way that we can never exist. Briefly, here are the issues that divide Candrakīrti (and me) from 
Thompson and the Pudgālavādins: First, Candrakīrti argues that we are constituted not in isolation, but in ensemble. Candrakīrti's use of terms like samvṛti, vyavahāra, lokaprasiddhi, et cetera are meant to convey the public, transactional creation of personae, masks - temporary, shifting identities determined not only by those who wear the masks, but those who assign them identities and meaning. I am a teacher, a son, a father, an American, an Australian, a Singaporean, a friend of Thompson's, a critic of Thompson's, et cetera. These are public roles, not roles I create on my own, but which are created in my interaction with others, and they, not my own psychological processes, constitute my shifting identities.

Second, the apparent unity to my experience is a construction. If to be a self is to be a subject, a unified center of consciousness, we are not selves. Persons, yes, but not selves. Our subjectivity is too complex, too fragmented, too multilayered for that. The transcendental unity of apperception that Kant thought was necessary to our identity (an idea carried over through Husserl into Thompson's thinking) is, from the standpoint of Buddhist philosophy and from a lot of cognitive science, alas, not even actual. Agency is equally fragmented. Our sense that there is a unity of decision making when we act is simply false. The springs of action are manifold, and we often rationalize our motives ex post facto.

These are precisely the phenomena to which Candrakīti as well as Asanga and Vasubandhu advert when they say that the self as a narrative center of gravity (to use Daniel Dennett's apt term) or as a center of agency or as something supervenient upon our aggregates - the thing to which we take ourselves to advert when we say "I" - simply is non-existent. What Thompson takes to be a real construction is, from the standpoint of those with whom he wishes to ally himself, simply an illusion. ${ }^{1}$ And I go with them. What is real, instead, is the person, a loose set of conventions with no center, no unity, no persistence. I hope that Thompson follows Candrakirti down the path of the meditation on selflessness. It is scary, but it takes one in the right direction.

\section{Consciousness}

On to consciousness. The song remains the same. Just as Thompson reifies the self in his sincere effort to desubstantialize it, he treats consciousness as a thing, even as he recognizes its multiple kinds and instances. So, for instance, early in the book Thompson wonders about consciousness in deep sleep:

If deep sleep is peaceful and blissful, does this mean that we're somehow conscious in deep sleep? Is awareness present, or is deep sleep the oblivion of awareness? Put another way, is deep sleep a state of consciousness, like waking and dreaming, or is it a state where consciousness is absent... ? (p. 5)

"Is consciousness present or absent?" we are invited to wonder. But let us first wonder about the referent of the term. Of what are we asking, "Is it present or absent?" Now Thompson has distinguished several senses of consciousness-creature, access, phenomenal_and so he recognizes that the phenomenon he is addressing is 
not simple. That is to be commended. But in cases like this, and in the following passage where he wonders whether consciousness is punctual or fluid, we still find it treated as a thing - whether a process or a property, or whatever - that is never clear, it is something that can be there or not:

According to the Abhidharma philosophers, what appears as a uniform stream of consciousness to the untrained observer is really an articulated sequence of discrete moments of awareness. . . Maybe premeditative consciousness is discrete and not uniform. Maybe premeditative consciousness is uniform and Vipassanā meditation makes it discrete. (pp. 56-57)

What is wrong with this? It is, I fear, a mystification. I am right now far from Thompson. And he is far from me. Does that mean that our far-from-each-otherness is present? And where does it go when we meet at a conference? Is it continuous or punctual? Is my farness from Thompson the same as or different from his farness from me? Just as we can use the first-person pronoun without positing a self to which it must refer, we can talk about being conscious, and indeed about many ways of being conscious, without positing consciousness, by virtue of which we are conscious. One of the more puzzling problems in the contemporary industry of consciousness studies is the move from the adjective or the relation to the putative property or phenomenon that is presumed to make it possible to be conscious. One sign of this mystification is the hardness of the so-called "hard problem," which, I suspect, derives not from the difficulty of explaining the obviously real phenomenon of consciousness in physical terms, but from the difficulty of identifying anything to explain. We see some of this in Thompson's own comments:

Here's the crucial deeper message: Consciousness itself has not and cannot be observed through the scientific method, because the scientific method gives us no direct and independent access to consciousness itself. So the scientific method cannot have the final say on matters concerning consciousness. (pp. 96-97)

Well, that may be so, just as it cannot have the final say on the true nature of the tooth fairy, but perhaps for the same reason. What is it about consciousness that is supposed to convince us both that it is a real phenomenon of its own and that science can tell us nothing about it? It doesn't explain any other phenomenon; while we must be conscious in some sense to observe things or to ask about consciousness, we don't ever observe it, on pain of regress. And we can't say anything determinate about it, except to note its mysteries.

Here is Thompson a few pages later:

The upshot is that there is no way to stand outside of consciousness and look at it, in order to see how it fits into the rest of reality. Science always moves within the field of what consciousness reveals; it can enlarge this field and open up new vistas, but it can never get beyond the horizon set by consciousness. In this way, direct experience is primary and science secondary.

Consciousness is our way of being, and it cannot be objectified, that is, treated as just another kind of object out there in the world, because it is that by which any object shows up for us at all. (p. 100) 
This last remark actually gets things just right. It is not a thing, not an object, not a phenomenon. If we are using the word "consciousness" not to refer to a thing to be explained, to a feature of the objective world, but just to our Dasein-our mode of being-it is no thing at all, and there is nothing to explain, no problem. Dasein, after all, can never be one more being in the world; it is rather the way in which beings exist. When I manifest as a teacher in the classroom, there is a way that I teach, but not three things: me, my teaching and a way. And if we asserted that ways of being emerged from beings, we would be properly ridiculed.

That is why there is not only no special problem for science here; there is no special problem about consciousness for us as conscious beings. The mystery of consciousness is simply the mystery of being, the fact that we exist as subjects and have worlds. And that is no mystery at all. It is just the fact that sufficiently complex biological organisms like us perceive, think, interact, care, and engage in complex ways with each other and our environment. All of that can be explained, and to think that there is then some residue is like thinking that we can explain everything, but leave out the self. There is no self; there is no thing called consciousness. But then why does Thompson continue as follows?

\begin{abstract}
My view can be described as an emergentist one, in the following sense. I hold that consciousness is a natural phenomenon and that the cognitive complexity of consciousness increases as a function of the increasing complexity of living beings. Consciousness depends on physical or biological processes, but it also influences the physical or biological processes on which it depends. I also think the human mind is capable of understanding how consciousness arises as a natural phenomenon, so I'm not a mysterian.
\end{abstract}

... In my view, however, no concept of nature or physical being that by design excludes mental or experiential being will work to account for consciousness and its place in nature.

I take this conclusion to follow from the primacy of consciousness discussed above. Since consciousness by nature is experiential, and experience is primary and ineliminable, consciousness cannot be reductively explained in terms of what is fundamentally or essentially non-experiential. (p. 103)

Here Thompson oscillates between the steady naturalism to which his experience in cognitive science leads him, grounding the nature of our subjectivity in our biology (I, with Candrakìrti, would add our social context and psychology-but no matter) and then taking consciousness to arise as a new phenomenon. It feels to me like asking how football arises from twenty-two guys kicking a ball around a field according to FIFA rules. Yes, it is natural, but no it cannot be reductively explained. Nonetheless, it is not a new thing. It just is those guys doing that rule-governed thing. The mystery is hard to find, and the distinction between the non-experiential and the experiential is just more smoke and mirrors.

\title{
Reflexive Awareness
}

The smoke gets thicker when we turn consciousness into a kind of inner mirror in the context of analyzing it as reflexive awareness, a temptation to which Thompson 
succumbs partly in the thrall of Yogācāra Buddhism and partly due to the influence of Husserl and his contemporary interpreters. Candrakīrti, as Thompson is well aware, would have none of this (he is one of the most trenchant critics of the idea of the reflexivity of awareness), and neither should we. It is good to recall as we consider this problem that in India as well as Germany, the supposed reflexivity of awareness was dragged onto the philosophical stage in order to provide an analysis of consciousness. Saantarakșita, for instance, tells us that it is the characteristic that distinguishes sentience from insentience. We should be immediately suspicious when we are offered the essence of something that might not even exist. Here is Thompson on reflexivity:

When you see the sunset, your seeing isn't present to you as another object of awareness like the sunset. Neither is your seeing simply absent to you. Rather, your seeing reveals itself in the sunset's appearing to you visually. To use a grammatical metaphor, your awareness of the sunset is a transitive or object-directed awareness, but your seeing experience is intransitive and reflexive. In this way, your seeing is self-aware.

This kind of self-awareness isn't a higher-level, introspective, or reflective self-awareness. It's not a second-level awareness whose object is the first-level awareness. Rather it's contained within or belongs to the first-level awareness. ...

According to the self-illumination viewpoint, consciousness is self-luminous or selfrevealing. The traditional analogy is that of a light, which shows itself while illuminating the other things around it. A light illuminating other things doesn't require another light to be seen. So, consciousness, in revealing other things, doesn't need another consciousness to be revealed. (pp. 17-18)

My seeing isn't present to me as an object. That has to be right, on pain of regress. And there is a good sense in which it isn't absent, either: I am seeing. If I weren't, I wouldn't see the sunset. But to say that the seeing reveals itself is a bit much. How about this instead: The fact that I see a sunset allows me to infer that I am seeing. Just like the fact that I am now talking allows me to infer that I am alive. But my life does not reveal itself to me in my speech. Thompson is right to say that the selfillumination viewpoint regards consciousness as self-luminous like a lamp. But it also regards it as a thing, and it regards the metaphor of illumination, according to which this property or substance, or process, shines out on things in the world so that I can see them.

I think that is a terrible metaphor. Things in the world become apparent to us by virtue of their effects on us, not by virtue of a light we shine on them. They shine forth; we don't. We are aware of them, and only introspectively are we aware of that fact. Most of the time, the world is present to us with no reflection on our subjectivity. It is hard for philosophers to remember, but only a very small percentage of our time is spent reflecting on our experience, and when we do that, it is very explicit, very higher-order.

Only if you thought that that reflective mode is the normal mode of being would you take it as a paradigm; only if you had to explain that special property of process 
that is consciousness would you dream that it is characterized by reflexivity; only if you thought that there had to be some property of a self distinct from the biological and physical properties of living human beings that makes them conscious would you think that there is this thing called consciousness to be explained. And only if you did not take Candrakīti to heart would you think that.

It is easy to miss what Candrakīrti (or Hume) is trying to say. Thompson is trying to weave Vedānta and Buddhism together as the philosophical background against which to understand the fusion of phenomenology and cognitive science. But they represent very different perspectives. One posits a self whose essence is to be conscious, and whose consciousness in the end is entirely self-consciousness. That is the sat-cit-ananda of Śańkara's Vedānta. It is a profound tradition. The other rejects the self, rejects consciousness as anything more than a relation of perceiver to perceived and in its most mature moment rejects the reflexivity of consciousness. They are uneasy bedfellows, and I advise Thompson to give up on the threesome.

Note

1 - Compare the Müller-Lyer illusion. The "equality" of the two lines is not constructed; it is illusory. We can talk about the process of constructing the illusion, but not of the construction of the equality we take ourselves to see.

\section{References}

Candrakīrti. 1992. dBu ma la 'jug pa'i bshad pa. Sarnath: Kagyud Relief and Protection Society.

Dennett, Daniel C. 1992. "The Self as the Center of Narrative Gravity." In Self and Consciousness: Multiple Perspectives, edited by Frank S. Kessel, Pamela M. Cole, and Dale L. Johnson. New York: Psychology Press, 2014. First published in 1992 by Lawrence Erlbaum Associates.

Garfield, Jay L. 2015. Engaging Buddhism: Why it Matters to Philosophy. New York: Oxford University Press.

Thompson, Evan. 2015. Waking, Dreaming, Being. New York: Columbia University Press. 